\section{New pole for early opening of South Atlantic}

-Using the trends of equatorial, marginal fracture ridges, Le Pichon and Hayes ${ }^{1}$ proposed an early phase for the opening of the South Atlantic, with a pole of rotation at $21.5^{\circ} \mathrm{N}, 14^{\mathrm{W}}$ with respect to Africa. Francheteau and Le Pichon' ${ }^{2}$ tested this plate tectonic model with the whole South Atlantic and assumed that there is a relationship between continental margin offsets, the subsidence of coastal basins, and adjacent marginal fracture zones. We have studied extensions of fracture zones

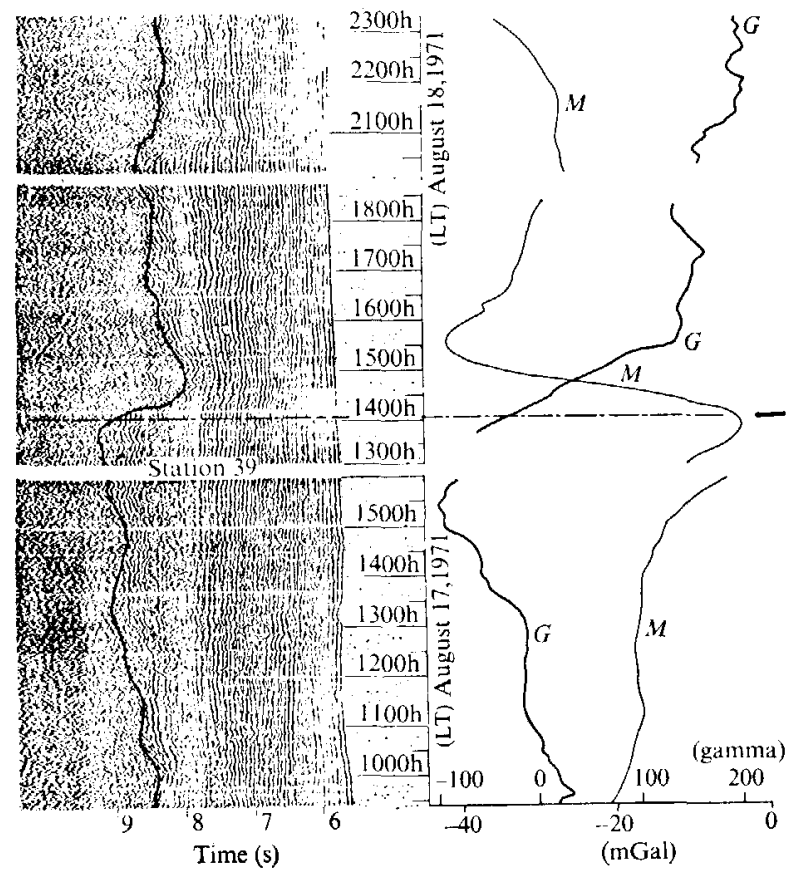

Fig. 1 Seismic profile across the Chain Fracture Zone south of Togo (location on Fig. 2). Note the difference in level of the acoustical basement under a thick sedimentary cover. The free air gravity anomaly is of the order of $40 \mathrm{mGal}$. The arrow indicates the theoretical location used for the determination of the trend of the fracture zone. $M$, Magnetic curve; $G$, gravity curve.

in the Gulf of Guinea and adjacent continental margins and have determined a new early opening pole that differs markedly from the one previously determined. -

Thanks to deeper penetration seismic techniques, extensions of the well known equatorial fracture zones ${ }^{3}$ have been traced into the Gulf of Guinea ${ }^{4-7}$ under a thick sedimentary cover mostly related to the Niger Delta. Figure 1 shows a seismic section across the extension of the Chain Fracture zone. It has been proposed ${ }^{\star}$ that the position of the inflexion point on the regional free-air anomaly curve corresponds to the main changes in the average basement level; consequently, seismic and gravity criteria have been used both together and separately to locate the position of the fracture zone. A structural trend called the Charcot Fracture Zone ${ }^{7,9,10}$ has been discovered just south-west of this delta (Fig. 2).

We have re-interpreted these results to obtain a better knowledge of the early opening phase of the Gulf of Guinea and consequently of the South Atlantic. The positions determined of the main geophysical features considered here are shown on Fig. 1. The Saint Paul Fracture Zone itself has not been taken into account, mainly because of its complex structural pattern near the Liberian continental margin" The trend of the Chain Fracture Zone previously inferred from bathymetric data ${ }^{1.5}$ is not compatible with our data (Figs 1 and 2 ). Parameters of our new pole are $32^{\circ} \mathrm{N}, 20^{\circ} \mathrm{W}$ (with a standard deviation of $6 \mathrm{~km}$ ).

The great circle defined by the two poles of rotation $\left(21.5^{\circ} \mathrm{N}, 14 \mathrm{~W}\right.$ and $\left.32^{\circ} \mathrm{N}, 20^{\circ} \mathrm{W}\right)$ cuts across the Liberian continental margin, the Walvis Ridge and the Aghulas Fracture Zone ${ }^{12,13}$ along a line close to the boundary that existed between Africa and South America before the opening of the ocean. Consequently, small circles about the two poles of rotation are tangential to each other, especially in the area where the great circle lies close to preopening boundaries. They diverge as the distance from the great circle increases, as in the eastern part of the Gulf of Guinea. Moreover, this effect decreases as the distance from the pole increases.

Figure 2 shows the small circles about each pole of rotation in the Gulf of Guinea. The direction of early opening which we propose fits well with the Liberian-Ivory Coast continental slope and with the limit of the Togo-Dahomey Basin. It also

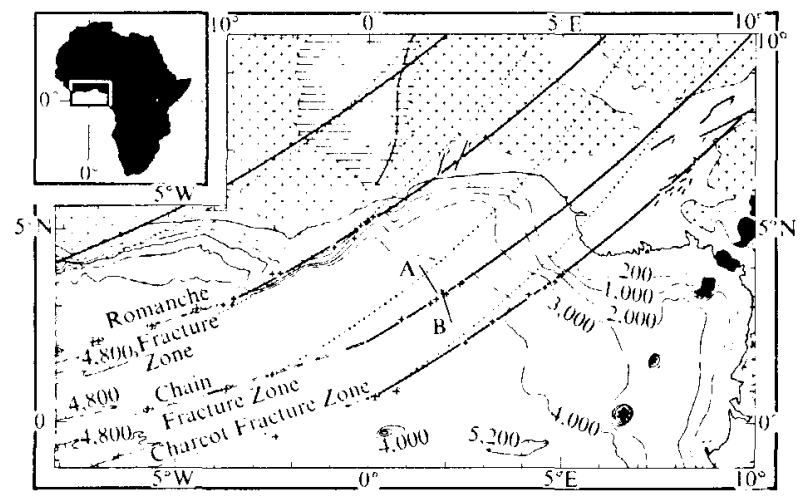

Fig. 2 Eastern Gulf of Guinea. Bathymetric contours ( $m$ ) from E. Uchupi (unpublished); geological sketch from the geological map of Africa ${ }^{19}$. Crosses, cratonic area; hatched, Palacozoic platform; dotted. Mesozoic to Recent basins; black area, Cameroon volcanic line. Heavy crosses, positions of geophysical features (from seismic, gravity, or magnetic surveys) uscd for computation of the new early pole of opening. Heavy black lines, portion of small circles about the new early pole along the SaintPaul, Romanche, Chain and Charcot Fracture zones. Note the good agreement between the extension of the two last fracture zones and the main geological trends in Nigeria. Dotted lines, portions of small circles about the previously proposed pole of opening ${ }^{1}$. Note the discrepancies with the geological trends in the Benoue Trough area. Double lines, posterior fracture zone trends. A-B indicates profile of Fig. 1.

agrees much better than did the previously proposed direction with the broad geological structure in Nigeria. It allows the extension of the Chain Fracture Zone to be related more easily with the northern hinge line of the Niger Delta ${ }^{14}$ and the northern limit of the Benoue Trough ${ }^{15}$. The Charcot Fracture Zone seems to correspond well with the complex Abakiliki area in southern Nigeria ${ }^{16}$.

Figure $3 a$ shows the good agreement between small circles about the new pole $\left(32^{\circ} \mathrm{N}, 20^{\circ} \mathrm{W}\right)$, and fracture trends in the vicinity of the Liberian continental margin ${ }^{11}$. Figure $3 b$ and $c$ represent, respectively, the eastermost section of the Walvis Ridge $^{17}$ and the Agulhas Fracture Zone ${ }^{12,13.18}$ on which a computed theoretical direction from the new pole has been superimposed. As expected from the orientation of the great 


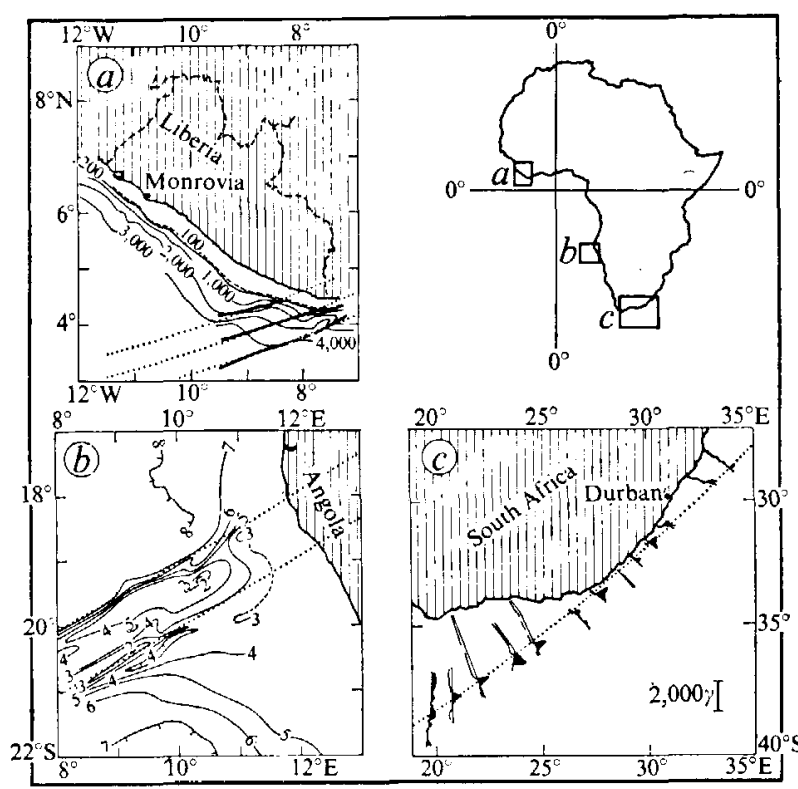

Fig. 3 Comparison between some western South Atlantic marginal structures and the new theoretical direction (small circles about a pole at $32^{\circ} \mathrm{N}, 20^{\circ} \mathrm{W}$ ). a, Liberian continental margins (depth contours in metres) and the Saint-Paul, Cape Palmas, Grand Cass fracture zones ${ }^{10} ; b$, depth (in seconds) of easternmost Walvis Ridge basement ${ }^{6}$; magnetic anomalies in the Agulhas Fracture Zone.

circle and the distance from the poles, the agreement in both cases is good. It is interesting to note that the easternmost Agulhas Fracture Zone differs somewhat from the theoretical direction but it should be specified that this fracture zone has for the most part been inferred from magnetic anomalies ${ }^{13}$. Those anomalies could be related partly to the continentaloceanic crust boundary instead of being representative of only the fracture zone itself.
Although in many cases this newly established evidence will have to be taken into account in any detailed reconstruction of the opening of the Atlantic, the conclusions of Francheteau and Le Pichon ${ }^{2}$ still seem to be valid.

We thank the scientific staffs of the RV Atlantis II and $R V$ Jean Charcot for the acquisition and the use of the data. X. Le Pichon and V. Renard critically reviewed this paper.

\section{Jean Mascle}

Jean-Claude Sibuet

Centre National de la Recherche Scientifique,

Centre Océanologique de Bretagne,

B.P. 3.37, 29273, Brest, France

Received May 14; revised August 30, 1974.

${ }^{1}$ Le Pichon, X., and Hayes, D. E., J. geophys. Res., 76, 6283-6293 (1971)

${ }^{2}$ Francheteau, J., and Le Pichon, X., Bull. Am. Ass. Petrol. Geol., 56, 991-1007 (1972).

${ }^{3}$ Heezen, B. C., Bunce, E. T., Hersey, J. B., and Tharp, P., Deep Sea Res., 11, 11-22(1964).

${ }^{4}$ Fail, J. P., et al., Earth planet Sci. Lett., 7, 413-419 (1970).

5 Arens, G., et al., SCOR Symposium, Cambridge, 1970, 65-78 (Inst. Géol. Sci., 1971).

${ }^{6}$ Mascle, J., and Renard, V., EOS, Trans Am. geophys. Un., 54, 477 (1973).

${ }^{7}$ Delteil, J. R., et al., in Continental Margins of the World, (Drake and Burk, in the press)

${ }^{8}$ Sibuet, J. C., Le Pichon, X., and Goslin, J., Nature (in the press).

9 Mascle, J., Bornhold, B. P., Renard, V., Bull. Am. Ass. Petrol. Geol, 57, 1672-1678 (1973).

10 Pautot, G. Renard, V., Daniel, J., and Dupont, J., ibid., 57, 1658-1671 (1973).

${ }^{11}$ Behrendt, J. C., Schiee, J., and Robb, J. M., Nature, 248, 324-326 (1974).

12 Talwani, M., and Eldholm, O., Nature, 241, 325-330 (1973)

${ }_{13}$ Scrutton, R. A. and du Plessis, A., Nature, 242, 180-182 (1973).

${ }^{14}$ Merki, P., Conf. on African Geology, Ibadan, 1970, 635-646 (1972).

${ }^{15}$ Cratchley, C. R., and Jones, G. P., Overseas Geol. Surv. Geophysical Paper no. 1 (1965).

${ }^{16}$ Short, K. C., and Stäuble, A. J., Bull. Am. Ass. Petrol. Geol., 51, $761-779$ (1967).

${ }^{17}$ Goslin, J., Mascle, J., Sibuet, J. C., and Hoskins, H., Bull. geol. Soc. Am., 85, 619-632 (1974).

18 Larson, R. L., and Ladd, J. W., Nature, 246, 209-212 (1973).

19 Geological map of Africa, Sheets 4 and 5 (Unesco, Paris, 1963). 